Portland State University

PDXScholar

\title{
An Activity-Based Learning Module for Human Factors in the Introductory Transportation Engineering Course
}

David Hurwitz

Oregon State University

Follow this and additional works at: https://pdxscholar.library.pdx.edu/trec_reports

Part of the Transportation Commons, and the Urban Studies and Planning Commons Let us know how access to this document benefits you.

\section{Recommended Citation}

Hurwitz, David. An Activity-Based Learning Module for Human Factors in the Introductory Transportation Engineering Course. OTREC-ED-13-03. Portland, OR: Transportation Research and Education Center (TREC), 2013. https://doi.org/10.15760/trec.48

This Report is brought to you for free and open access. It has been accepted for inclusion in TREC Final Reports by an authorized administrator of PDXScholar. Please contact us if we can make this document more accessible: pdxscholar@pdx.edu. 


\section{(3) \\ O REC \\ EDUCATION PROJECT SUMMARY REPORT

\section{An Activity-Based Learning Module for Human Factors in the Introductory Transportation Engineering Course}

OTREC-ED-13-03

September 2013

Additional information about this project, including associated project deliverables, can be found at http://otrec.us/project/517 



\section{ABOUT THIS PROJECT SUMMARY REPORT}

The purpose of an OTREC Education project is to immediately enhance educational opportunities for OTREC graduate and undergraduate students, and subsequently for students at universities throughout the United States as the results of the project are disseminated.

In most cases, the result of an Education project is a new course or module, including curriculum materials, lesson plans and related resources. The purpose of this project summary report is to document the project's methodology and outcomes. The deliverables may be included directly or by reference, but will always be readily available on the project's webpage at http://otrec.us.

We expect that this report will be primarily of value to researchers who may be considering a project to replicate or adapt, or who want to apply the lessons learned through the way this project was conducted rather than use its results. We encourage you to contact the principal investigator or OTREC staff for further information.

\section{ACKNOWLEDGEMENTS}

Members of the National Transportation Curriculum Project (Michael Kyte at the University of Idaho, Andrea Bill at the University of Wisconsin Madison, Rhonda Young at the University of Wyoming, Kevin Heaslip at Utah State University, Kristen Sanford Bernhardt at Lafayette College, and Rod Turochy at Auburn University) were instrumental in the execution of the Transportation Engineering Educators Workshop. This project would not have been a success without their tireless efforts.

The author gratefully acknowledges the commitment and contributions of the workshop participants and the graduate students who contributed to the workshop at all levels.

Chris Monsere, associate professor at Portland State University contributed ideas and curricula materials to the Human Factors materials, and the resulting product benefited greatly from his contribution.

Additionally, this material is based upon work supported in part by the National Science Foundation under Grant No. DUE-1235896. Any opinions, findings, and conclusions or recommendations expressed in this material are those of the author(s) and do not necessarily reflect the views of the National Science Foundation. 


\section{DISCLAIMER}

The contents of this report reflect the views of the authors, who are responsible for the facts and the accuracy of the information presented herein. This document is disseminated under the sponsorship of the U.S. Department of Transportation's University Transportation Centers Program, in the interest of information exchange. The U.S. Government assumes no liability for the contents or use thereof. 


\title{
AN ACTIVITY-BASED LEARNING MODULE FOR HUMAN FACTORS IN THE INTRODUCTORY TRANSPORTATION ENGINEERING COURSE
}

\section{PROJECT SUMMARY REPORT}

\author{
OTREC Project No. 2012-517 \\ Principal Investigator: David Hurwitz \\ University Affiliation: Oregon State University \\ Project Website: http://otrec.us/project/517
}

\section{INTRODUCTION}

This project summary report describes the execution of OTREC Project \#517 (An ActivityBased Learning Module for Human Factors in the Introductory Transportation Engineering Course).

\section{MOTIVATION}

The development of the transportation engineering workforce at the university level is typically promoted through civil engineering programs. Nearly all of the nation's 224 civil engineering programs have one or two required transportation courses as part of their undergraduate program (Bertini, 2009). Some civil engineering sub-disciplines, such as geotechnical, materials, structures and hydraulics, have a logical sequence of required prerequisite courses leading to the required junior-level courses. For other disciplines, the logical sequence is less clear. This scenario is certainly the case for the typical progression of transportation engineering courses. A lack of clarity and connection with other sub-disciplines poses significant challenges for faculty, students and practitioners in transportation engineering. It is likely that these challenges negatively impact the "pipeline," or educational path to employment, that is so commonly discussed when considering transportation workforce development.

This educational development activity addresses undergraduate transportation education by concentrating exclusively on the most commonly offered junior-level introductory transportation engineering course. This introductory class serves as the initial exposure to the field of transportation engineering in many civil engineering programs. If we are to promote undergraduate transportation engineering education and attract more students to the profession, this initial exposure is critical.

This work provides resources for transportation educators across the country to re-envision the content that should be considered as critical to the course (knowledge table). The work also 
ultimately provides detailed documentation of learning activities that may be employed for the content area of "Human Factors and Driver Behavior."

Additionally, because the focus of the work is a Human Factors and Driver Behavior module, we are contributing to the U.S. Department of Transportation a priority research cluster of Human Factors, which the Research and Innovative Technology Association (RITA) says, "focuses on the human interactions with infrastructure and conveyances that operates over them" (RITA, 2011).

\section{REPORT ORGANIZATION}

The remainder of this technical memo describes the educational activities that were conducted as part of this OTREC-sponsored project. These activities included hosting a workshop on activitybased learning, developing a framework for the Human Factors content that should appear in an introduction to transportation class, and the development/refinement of learning activities.

\section{EDUCATIONAL ACTIVITIES}

\section{Workshop on Activity-Based Learning}

A two-day workshop (July 31 and Aug. 1, 2012) dealing with activity-based learning was held on the University of Washington campus in Seattle. The workshop included lectures from nationally recognized transportation engineering experts and provided significant hands-on experience for transportation engineering faculty to learn more about the activity-based learning process, to develop prototype activities, and to review and test these prototypes with other members of the educational community.

The original motivation and idea for the conference was this OTREC project. To entice more notable speakers and a larger pool of participants, a second proposal was submitted to the National Science Foundation (NSF). The NSF proposal was successful and provided additional resources to support participant and speakers' travel. In total, 60 participants attended the conference, including 45 professors, six government employees, and nine near-completion Ph.D. students. This population was geographically diverse, as shown in Figure 1. 


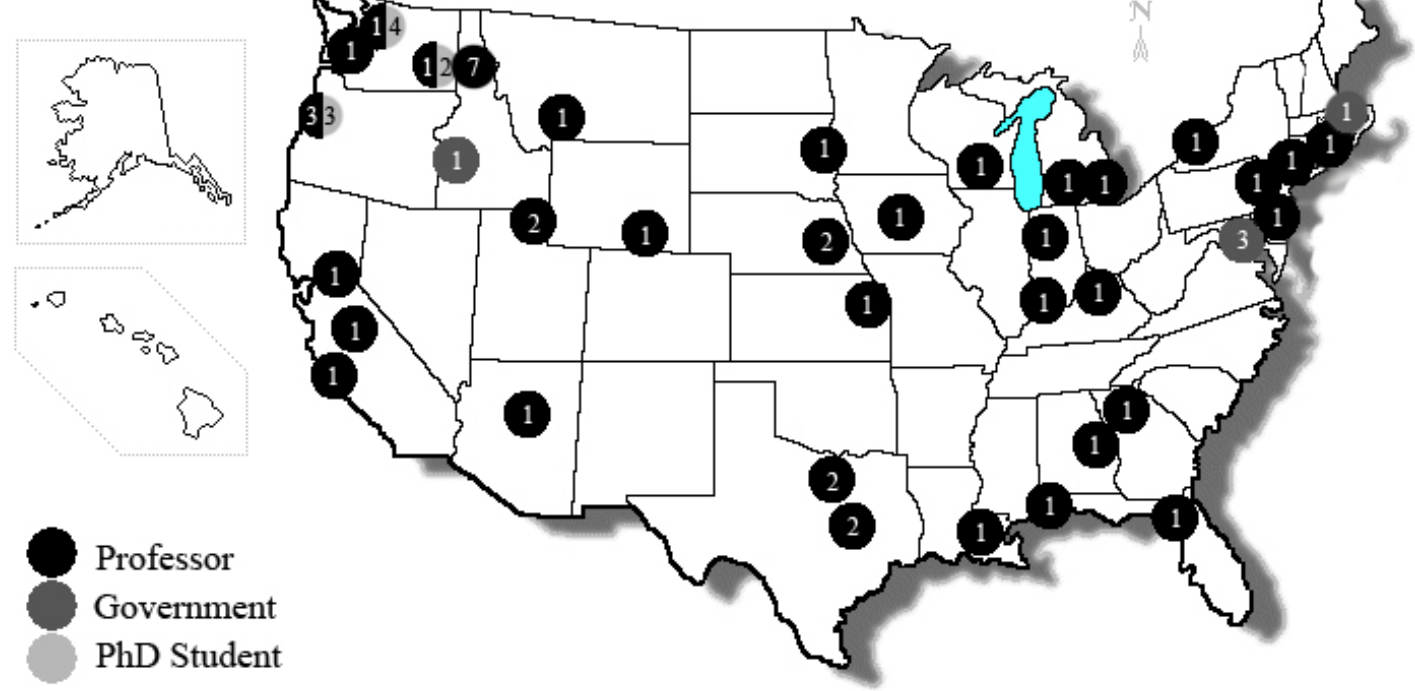

Figure 1 Transportation Engineering Educator's Conference Participants

The majority of the two-day workshop was spent with groups of faculty working in teams of six, which were organized in one of four content areas: operations, design, planning and safety. The group brainstorming sessions were interspersed with lectures from nationally recognized experts in engineering education. Figure 2 shows images of Steven Beyerlein, professor of mechanical engineering at the University of Idaho, speaking to workshop participants about the execution of learning activities in the classroom.

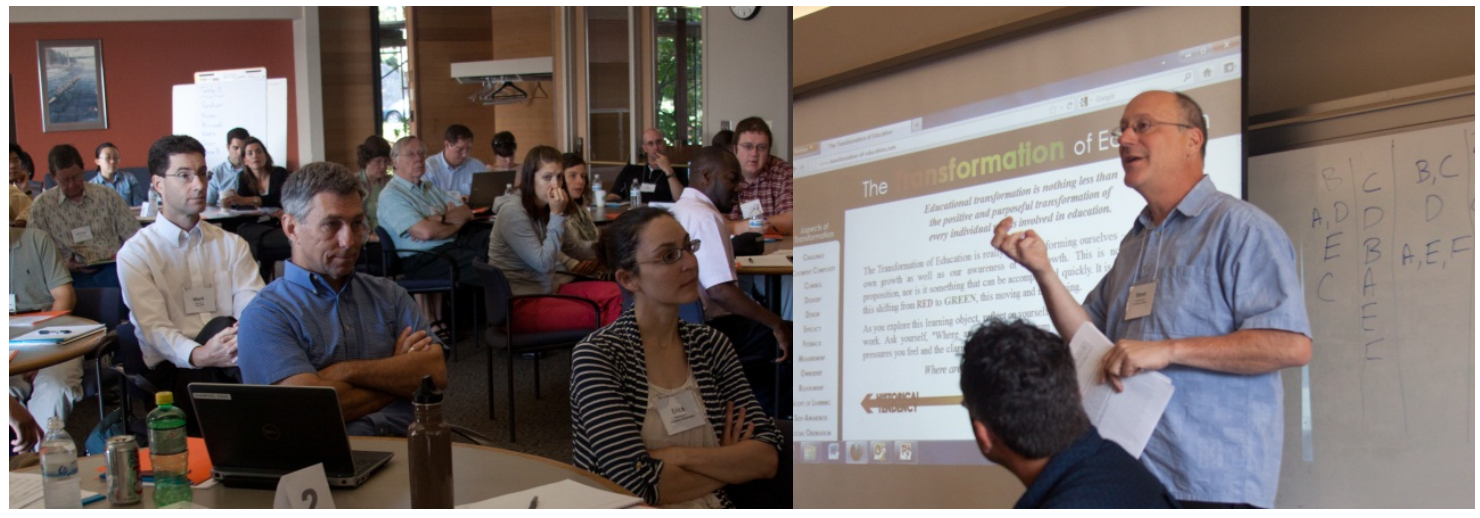

Figure 2 Workshop Participants and Technical Lecturer

The result of the group brainstorming activities was the development and hard copy documentation of over 100 individual ideas for learning activities in each of the four core content areas. These brainstorming materials have been digitized and may be accessed at the following website location: http://nationaltransportationcurriculumproject.wordpress.com/. These materials are currently being transcribed and refined to be more easily adopted by the broader community of transportation engineering educators. The process by which these materials are being refined is described in Figure 3. The grey box with blue writing is an example of one idea that was developed by a group working on basic statistical techniques critical to the study of transportation safety. Once the idea was articulated by the expert group, a graduate student and a 
faculty advisor refined and further developed the idea, finally producing an organized ranking task shown in the lower left box of Figure 3. This process is currently being undertaken for all of the materials that were developed during the workshop.

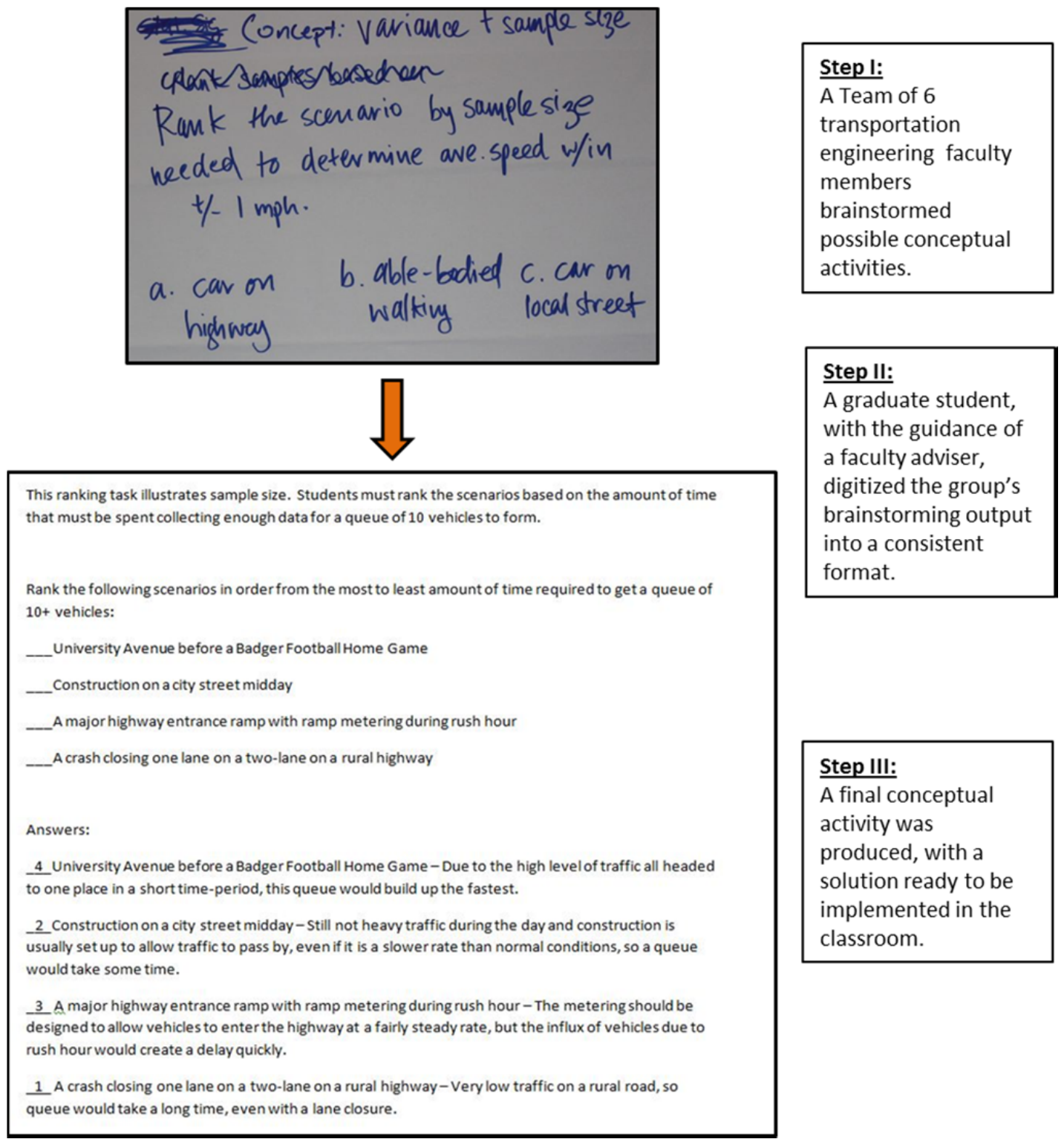

\section{Figure 3 Notes from a Safety Group on a Sample Size Ranking Task}

\section{Framework for Human Factors and Driver Behavior}

The framework for Human Factors and Driver Behavior development took the form of a knowledge table that was designed by the research team and reviewed by the workshop conference participants. The purposes of knowledge tables are to identify the content that students are expected to learn, and to provide guidance on how students can effectively learn and apply this knowledge (Quarless, 2007). The research team utilized Bloom's taxonomy (Forehand, 2005) and Wiggins and McTighe's (1999) "levels of understanding" to provide guidance on what the students would be expected to do with the knowledge they had learned. The research team used both classification systems as bases to 
encourage instructors to pursue a deeper understanding of the topics, in order to stimulate students' interest in the profession. A knowledge table was created to provide a reference for helping instructors develop course topics and assessment tools, and not with the intent of dictating course content. This knowledge table represents a consensus of what students should learn from Human Factors and Driver Behavior content. The knowledge table is included in Figure 4.

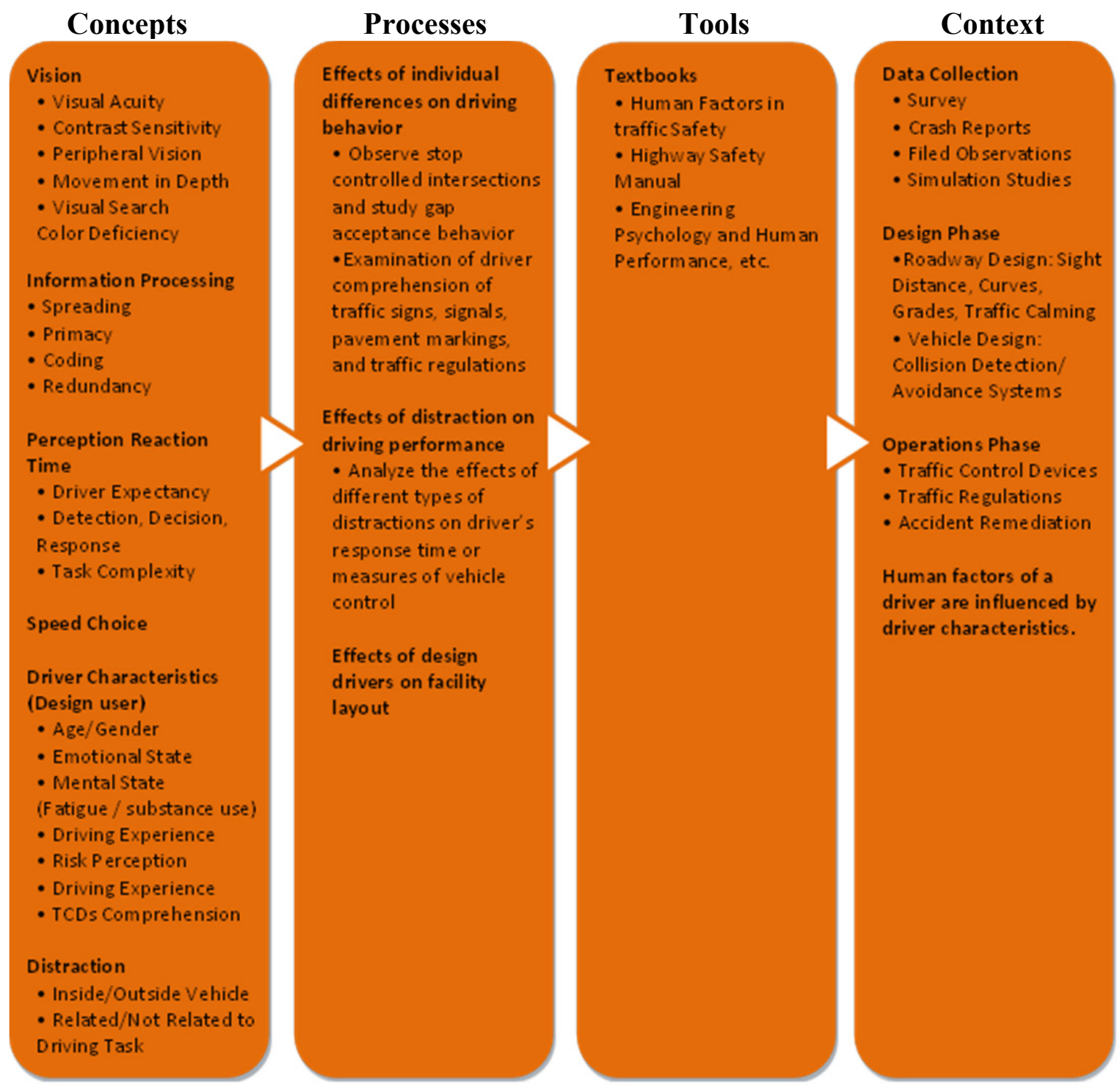

Figure 4 Human Factors and Driver Behavior Knowledge Table

The knowledge table represents a starting point for curriculum development. The next step is to develop of an active-learning module that could form the basis for what students will actually do in an introductory transportation course related to Human Factors and Driver Behavior.

\section{Develop Human Factors and Driver Behavior Activities}

Thirteen learning activities encompassing a sequence of pre-class, in-class and post-class tasks were developed in four topics central to Human Factors and Driver Behavior (i.e., attention and information processing, perception reaction time, speed selection, and vision). Table 1 presents 
the organization of the 13 activities across the topics and their sequence. The activity outlines are available for dissemination on the project website

(http://nationaltransportationcurriculumproject.wordpress.com/).

Table 1 Map of Human Factors and Driving Behavior Activities

\begin{tabular}{|c|c|c|c|c|}
\hline \multirow[b]{2}{*}{$\begin{array}{l}\text { Timing of } \\
\text { Activity }\end{array}$} & \multicolumn{4}{|c|}{ Activities } \\
\hline & $\begin{array}{l}\text { Attention and } \\
\text { Information } \\
\text { Processing }\end{array}$ & $\begin{array}{c}\text { Perception } \\
\text { Reaction Time }\end{array}$ & Speed Selection & Vision \\
\hline Pre-Class & $\begin{array}{c}\text { HSM reading and } \\
\text { questions }\end{array}$ & $\begin{array}{c}\text { HSM reading and } \\
\text { questions }\end{array}$ & $\begin{array}{l}\text { HSM reading and } \\
\text { questions }\end{array}$ & $\begin{array}{c}\text { HSM reading and } \\
\text { questions }\end{array}$ \\
\hline In-Class I & $\begin{array}{l}\text { Eye-tracking data } \\
\text { reduction }\end{array}$ & $\begin{array}{l}\text { PRT Analysis } \\
\text { from video }\end{array}$ & $\begin{array}{c}\text { Speed data } \\
\text { analysis from } \\
\text { video } \\
\end{array}$ & $\begin{array}{l}\text { Visual acuity } \\
\text { activity }\end{array}$ \\
\hline In-Class II & $\begin{array}{c}\text { Cognitive loading } \\
\text { video }\end{array}$ & & & \\
\hline Post-Class & $\begin{array}{c}\text { HFs in traffic } \\
\text { safety reading and } \\
\text { questions }\end{array}$ & $\begin{array}{l}\text { Field work at an } \\
\text { intersection }\end{array}$ & $\begin{array}{c}\text { HFs in traffic } \\
\text { safety reading and } \\
\text { questions }\end{array}$ & $\begin{array}{c}\text { HFs in traffic } \\
\text { safety reading and } \\
\text { questions }\end{array}$ \\
\hline
\end{tabular}

\section{PROJECT OUTCOMES}

Several notable outcomes resulted from this project. These outcomes may be aggregated into three categories: workshop on active learning, framework for activity development in Human Factors and Driver Behavior, and the specific learning activities themselves. These outcomes are described below:

- This OTREC Educational project served as seed funding for a successful NSF proposal.

- A two-day workshop was conducted, contributing to the training of 60 participants in the development and execution of learning activities related to transportation engineering.

- Over 100 learning activities were brainstormed and outlined by professors from around the country (http://nationaltransportationcurriculumproject.wordpress.com/).

- A framework for the Human Factors and Driver Behavior content was developed, refined and disseminated to professors across the country.

- Thirteen Human Factors and Driver Behavior learning activities designed to take place before, during and after class were developed and disseminated to professors from around the country (http://nationaltransportationcurriculumproject.wordpress.com/).

\section{ONLINE APPENDICES}

The project website (http://otrec.us/project/517) includes a number of related materials, including the 13 Human Factors and Driving Behavior learning activities mentioned above and some accompanying videos. 


\section{REFERENCES}

Bertini, R. and M. Kyte. Proceedings from the Transportation Education Conference. http://www.webs1.uidaho.edu/transportation_education_conference2009/TEC\%20Final\%202010-04-21.pdf

RITA, TD\&T, (2011) DOT Research Clusters. Accessed at http://www.rita.dot.gov/rdt/dot_research_clusters.html\#4.

Forehand, Mary. (2005) Bloom's Taxonomy: Original and Revised. E-Book: Learning, Teaching, and Technology. Accessed at http://eit.tamu.edu/JJ/DE/BloomsTaxonomy.pdf.

Quarless, D. (2007) Forms of Knowledge and Knowledge Tables. In Faculty Guidebook, 4th Edition, Beyerlein, S. et al. eds. Pacific Crest.

Wiggins, G., \& McTighe, J. (1999). Understanding by Design. Englewood Cliffs, NJ: PrenticeHall. 
